\title{
Efficiency of Seed Treatment for Control of Chick Pea Wilt Disease caused by Fusarium oxysporum F. sp. ciceri
}

\author{
Ravi Prakash Mishra ${ }^{1 *}$, Manjul Pandey ${ }^{2}$, Vibhuti Gupta $^{3}$ and Deepali Bakshi ${ }^{1}$ \\ ${ }^{1}$ Department of Agriculture, CGC Technical Campus \\ Jhanjeri-Mohali (Punjab) 140307, India \\ ${ }^{2}$ Banda KrashiVigyan Kendra, Banda (UP) 200001, India \\ *Corresponding author
}

\section{A B S T R A C T}

\section{Keywords}

Chick pea,

Fusarium wilt,

Trichodermaviride,

Seed treatment

Article Info

Accepted:

22 November 2020

Available Online:

10 December 2020
Pulses are an important ingredient in the diet of a vast majority of Indian population as they provide a perfect mixture of high nutritional value when supplemented with cereals. Chickpea productivity is constrained by several abiotic and biotic stresses. In India, estimated 10 per cent annual losses in chickpea yield due to Fusarium wilt. Control of the wilt disease by doing seed treatment with systemic fungicides and other bio-control agents is more effective. The result concluded that out of sixteen treatment including control $\mathrm{T}_{5}$ treatment (T.v. + Vitavax) as well as Vitavax are better seed treatments to enhance quality seed parameters, which then converted into superior yield even in adverse conditions. Seed treatment with Trichoderma viride+ Vitavax were fund superior for germination (82\%) and plant survival respectively, seed treatment with bio agent and Vitavax gave the highest yield per plot and found the superior seed treatment. Among all the treatments, Chlorophyriphos + Rhizobium exhibited the poorest performance in most of the character under study over control.

\section{Introduction}

Role of pulses in agriculture needs hardly any emphasis. The pulses are an integral part of the cropping system of the farmers all over the country because these crops fit well in the crop rotation and crop mixture. Pulses are an important ingredient in the diet of a vast majority of Indian population as they provide a perfect mixture of high nutritional value when supplemented with cereals. Chickpea was one of the first grain legumes domesticated in the old world (van der Maesen, 1987). Ladizinsky and Alder (1976a) considered Cicerreticulatum as the wild progenitor of chickpea and South-Eastern Turkey as the centre for origin of the crop.

In India, the earliest record of chickpea dated at 2000 B.C from Atranjikhera in Uttar Pradesh. The main chickpea producing states are Uttar Pradesh, Punjab, Haryana, Bihar, 
Madhya Pradesh, Rajasthan and Maharashtra. Chickpea productivity is constrained by several abiotic and biotic stresses. Among the abiotic stress, high temperature is a major factor, associated with yield reduction (Summerfield et al., 1990).Among the biotic stresses, diseases and insect-pests are the major yield limiting factors causing a yield loss of about 30 percent. In India, Singh and Dahiya (1973) estimated 10 per cent annual losses in chickpea yield due to Fusarium wilt. Several practices such as cultural, biological and chemical can control Fusarium wilt disease. Cultural practices involves avoid sowing of seed at high temperature, deep sowing and soil amendment with oilseed cakes, crop rotation to minimize pathogen population, deep ploughing during the hot summer and soil solarisation, whereas chemical control of the wilt includes seed treatment with systemic fungicides. Control of plant disease particularly those, which are soil borne in nature through biological agents has now become an integral part of plant disease control measures, mainly due to hazardous effects of chemicals in soil and environment. Fusarium oxysporum f. sp. ciceri, the causative agent of chickpea wilt has been appearing in severe form for long time and causing a major problem in chickpea growing parts of the country.

Therefore, in view of the seriousness of the disease and importance of the crop, it became important to study in detail regarding the disease, pathogen as well as the management of disease by applying biological agent Trichoderma. Trichoderma commonly available in soil and root ecosystem has gained immense importance since, last few decades due to its biological control ability against several plant pathogens (Kubicek et al., 1998 and Harman et. al., 1996). Antagonistic microorganisms, such as Trichoderma reduce growth and survival of the pathogen by different mechanism like competition, antibiosis, mycoparasitism, hyphal interactions and enzyme secretion. Such microorganisms are now available commercially and used in crop management and practices (Singh, et al., 2006; Muhopadhyay, 2009).

\section{Materials and Methods}

The field experiment conducted during 20122013 in a design consisting of seed treatment with pesticides in combination with bioagent (Trichoderma viride). Seeds sown without any treatment considered as check (control). The soil inoculated with inoculum of Fusarium oxysporum f. sp. ciceri @ 5.0 g/m². The inoculum mixed with the seeds before the sowing. The soil in the field was sandy loam in texture with $\mathrm{pH} 7.2$, organic matter 0.4 per cent with medium fertility status and medium water holding capacity.

Seeds of susceptible variety (K-850) sown. Wilting of plant monitored right after emergence of seedlings to crop maturity. Wilt incidence, per cent wilt control and per cent increase in yield over check also observed. Chickpea seeds of the most susceptible variety (K-850) treated with antagonists Trichoderma viride sown in $9 \mathrm{~m} \times 3 \mathrm{~m}$ size wilt sick plot at the CSAUA\&T, Kanpur to test the efficiency of the bioagent during the Rabi season of 2012-2013.

The experiment was sown in RBD. The untreated seeds served as control. Recommended doses of bio-control agent, fungicides, insecticide and bio-fertilizer ( $T$. viridebio formulation) @ 4g/kg seed, Vitavax @ 2g/ kg seed, Chlorpyriphos 20 EC @ 8 $\mathrm{ml} / \mathrm{kg}$ seed and Rhizobium culture @ $2.5 \mathrm{~g} / \mathrm{kg}$ seed) applied to one hundred seeds (counted and weighed) were sown in three replications with 15 treatments and one without any seed treatment served as control. Following treatment combinations were used. 


\section{Treatment combinations}

\begin{tabular}{|c|c|c|}
\hline $\mathrm{T}_{1}$ & - & Trichoderma viride \\
\hline $\mathrm{T}_{2}$ & - & Vitavax \\
\hline $\mathrm{T}_{3}$ & - & Chlorpyriphos \\
\hline $\mathrm{T}_{4}$ & - & Rhizobium \\
\hline $\mathrm{T}_{5}$ & - & Trichoderma viride + Vitavax \\
\hline $\mathrm{T}_{6}$ & - & $\begin{array}{l}\text { Trichoderma viride } \\
\text { +Chlorpyriphos }\end{array}$ \\
\hline $\mathrm{T}_{7}$ & - & $\begin{array}{l}\text { Trichoderma viride }+ \\
\text { Rhizobium }\end{array}$ \\
\hline $\mathrm{T}_{8}$ & - & Vitavax + Chlorpyriphos \\
\hline $\mathrm{T}_{9}$ & - & Vitavax + Rhizobium \\
\hline $\mathrm{T}_{10}$ & - & Chlorpyriphos + Rhizobium \\
\hline $\mathrm{T}_{11}$ & - & $\begin{array}{l}\text { Trichoderma viride+ Vitavax } \\
+ \text { Chlorpyriphos }\end{array}$ \\
\hline $\mathrm{T}_{12}$ & - & $\begin{array}{l}\text { Trichoderma viride+ Vitavax } \\
+ \text { Rhizobium }\end{array}$ \\
\hline $\mathrm{T}_{13}$ & - & $\begin{array}{l}\text { Trichoderma viride }+ \\
\text { Chlorpyriphos }+ \text { Rhizobium }\end{array}$ \\
\hline $\mathrm{T}_{14}$ & - & $\begin{array}{l}\text { Vitavax + Chlorpyriphos + } \\
\text { Rhizobium }\end{array}$ \\
\hline $\mathrm{T}_{15}$ & - & $\begin{array}{l}\text { T. viride }+ \text { Chlorpyriphos }+ \\
\text { Vitavax }+ \text { Rhizobium }\end{array}$ \\
\hline $\mathrm{T}_{16}$ & - & Control \\
\hline
\end{tabular}

The seeds were primed for overnight in a suspension of the bio-agent separately. The seeds sown on the next day early morning in a well-pulverized plot of $9 \mathrm{~m} \times 3 \mathrm{~m}$ having three blocks of $3 \mathrm{~m} \times 3 \mathrm{~m}$ each. The distance between two rows kept as $30 \mathrm{cms}$.

Three rows sown for each treatment in a block. Regular observations taken at 10 days interval from 30 days after sowing. Number of plant counted row wise and fixed for further studies. Number of plants dead also counted at 10 days interval.

After five regular observations, number of plant survived counted and observations made for calculating the effectiveness of bio-agent in checking the attack of Fusarium oxysporum f. sp. ciceri on chickpea. Root length, shoot length was also measured.

\section{Results and Discussion}

The experimental results of different seed treatments in chickpea revealed significant different responses against all the four seed quality attributes. $\mathrm{T}_{5}$ treatment (T.v. + Vitavax) was found to be significantly superior and effective in increasing 16.67 per cent germination over control followed by $\mathrm{T}_{2}$ $(76 \%)$ and $\mathrm{T}_{1}(75 \%)$. Similarly the beneficial impact of seed treatment was also recorded for plant survival in which $T_{2}$ and $T_{5}$ treatment (Vitavax) and (T.v.+ Vitavax) excelled overall significant superior performance by contributing $73.66 \%$ both followed by $\mathrm{T}_{1}$ and $\mathrm{T}_{2}$ treatment (71\%) both.

The data given in Table 1 also revealed that over all superior performance was contributed by $\mathrm{T}_{5}$ treatment (T.v.+ Vitavax) achieving the highest germination as well as yield per plant. The result concluded that out of sixteen treatment including control $\mathrm{T}_{5}$ treatment (T.v. + Vitavax) as well as Vitavax are better seed treatments to enhance quality seed parameters, which then converted into superior yield even in adverse conditions.

Seed treatment with Trichoderma viride+ Vitavax were fund superior for germination $(82 \%)$ and plant survival respectively, seed treatment with bio agent and Vitavax gave the highest yield per plot and found the superior seed treatment. Among all the treatments, chlorophyriphos + Rhizobium exhibited the poorest performance in most of the character under study over control.

Verma and Vyas (1977) found the combined use of Corboxin and Carbendazim as seed treatment was effective against Fusarium wilt. Also worked on effect of seed treatment with fungicide and controlled chickpea wilt with use of Bavistin (Carbendazim). Adams (1990) studied on bio suppression of plant disease promoted as a means to achieve 
improved, sustainable crop production systems that are less reliant on chemical inputs. Mukhopadhyay et al., (1992) investigated alone of chickpea wilt and use Trichoderma alone a fungicide for seed treatment with Vitavax and Ziram resulted in $29.9 \%$ control. The control increased to 63.3\% with use of Trichoderma harzianum. De et al., (1996) investigated bio control agents (Bacillus subtilis, Gliocladium virens, Trichoderma harzianum, T. viride) and Corboxin significantly controlled Fusarium oxysporum f. sp. ciceri by 30-40 percent
Carbendazim was more effective than Corboxin reducing wilt incidence and increasing seed yield. Gholev and Kurundkar (2002) evaluated the efficacy of Trichoderma viride and Pseudomonas fluorescens isolated against wilt of pigeon pea in vitro with ICP $2376 @ 20 \mathrm{~g} / \mathrm{kg}$ seeds. All the treatment except seed treatment with Trichoderma viride alone increased seeding emergence and reduced wilt incidence. The greatest reduction in wilt incidence recorded for Trichoderma viride + Pseudomonas fluorescens isolate from chilli (Fig. 1-3).

Table.1 Evaluation of inhibitory effect of bio-agent with fungicides (Seed treatment)

\begin{tabular}{|c|c|c|c|c|c|c|c|c|}
\hline & Treatment & Germi-nation & $\begin{array}{l}\text { Root } \\
\text { length } \\
(\mathrm{cm})\end{array}$ & $\begin{array}{l}\text { Shoot } \\
\text { length } \\
(\mathrm{cm})\end{array}$ & $\begin{array}{l}\text { Seedling } \\
\text { length } \\
\text { (cm) }\end{array}$ & $\begin{array}{c}\text { Dry } \\
\text { weight }\end{array}$ & $\begin{array}{l}\text { Vigour } \\
\text { index I }\end{array}$ & $\begin{array}{l}\text { Vigour } \\
\text { index } \\
\text { II }\end{array}$ \\
\hline $\mathrm{T}_{1}$ & Trichoderma viride & 96.00 & 1.40 & 5.616 & 7.01 & 1.49 & 672.96 & 143.04 \\
\hline $\mathrm{T}_{2}$ & Vitavax & 97.66 & 1.33 & 6.02 & 7.35 & 1.60 & 717.8 & 156.25 \\
\hline $\mathrm{T}_{3}$ & Chlorpyriphos & 95.00 & 1.20 & 4.76 & 5.96 & 1.41 & 566.20 & 133.95 \\
\hline $\mathrm{T}_{4}$ & Rhizobium & 92.00 & 1.16 & 5.33 & 6.50 & 1.46 & 598.00 & 134.32 \\
\hline $\mathrm{T}_{5}$ & $\begin{array}{l}\text { Trichoderma viride }+ \\
\text { Vitavax }\end{array}$ & 99.00 & 1.90 & 7.12 & 9.02 & 1.72 & 892.98 & 170.94 \\
\hline $\mathrm{T}_{6}$ & $\begin{array}{l}\text { Trichoderma viride }+ \\
\text { Chlorpyriphos }\end{array}$ & 92.33 & 1.16 & 4.88 & 6.05 & 1.52 & 558.59 & 140.34 \\
\hline $\mathrm{T}_{7}$ & $\begin{array}{l}\text { Trichoderma viride }+ \\
\text { Rhizobium }\end{array}$ & 90.66 & 1.53 & 5.20 & 6.74 & 1.38 & 611.09 & 125.11 \\
\hline $\mathrm{T}_{8}$ & Vitavax + Chlorpyriphos & 92.66 & 1.20 & 4.82 & 5.88 & 1.37 & 544.84 & 121.38 \\
\hline $\mathrm{T}_{9}$ & Vitavax + Rhizobium & 88.66 & 1.30 & 4.89 & 5.98 & 1.38 & 530.18 & 122.35 \\
\hline $\mathrm{T}_{10}$ & Chlorpyriphos + Rhizobium & 90.33 & 1.16 & 5.5 & 6.66 & 1.49 & 601.59 & 134.59 \\
\hline $\mathrm{T}_{11}$ & $\begin{array}{l}\text { Trichoderma viride+ } \\
\text { Vitavax + Chlorpyriphos }\end{array}$ & 93.33 & 1.43 & 5.44 & 6.88 & 1.40 & 642.4 & 130.66 \\
\hline $\mathrm{T}_{12}$ & $\begin{array}{l}\text { Trichoderma viride+ } \\
\text { Vitavax }+ \text { Rhizobium }\end{array}$ & 93.00 & 1.33 & 5.88 & 7.21 & 1.53 & 670.53 & 142.29 \\
\hline $\mathrm{T}_{13}$ & $\begin{array}{l}\text { Trichoderma viride }+ \\
\text { Chlorpyriphos }+ \text { Rhizobium }\end{array}$ & 88.00 & 1.66 & 5.87 & 7.54 & 1.56 & 663.52 & 137.28 \\
\hline $\mathrm{T}_{14}$ & $\begin{array}{l}\text { Vitavax + Chlorpyriphos }+ \\
\text { Rhizobium }\end{array}$ & 87.33 & 1.33 & 4.99 & 6.32 & 1.46 & 524.56 & 127.50 \\
\hline $\mathrm{T}_{15}$ & $\begin{array}{l}\text { Vitavax }+ \text { Chlorpyriphos }+ \\
\text { Trichoderma viride }+ \\
\text { Rhizobium }\end{array}$ & 86.66 & 1.36 & 5.94 & 7.39 & 1.45 & 64.41 & 125.65 \\
\hline \multirow[t]{3}{*}{$\mathrm{T}_{16}$} & Control & 84.33 & 1.06 & 4.68 & 5.88 & 1.31 & 495.86 & 115.53 \\
\hline & CD at $5 \%$ & 2.99 & 0.14 & 0.44 & 0.45 & 0.12 & 41.88 & 17.27 \\
\hline & S.D & 1.41 & 0.07 & 0.20 & 0.21 & 0.06 & 19.75 & 8.14 \\
\hline
\end{tabular}



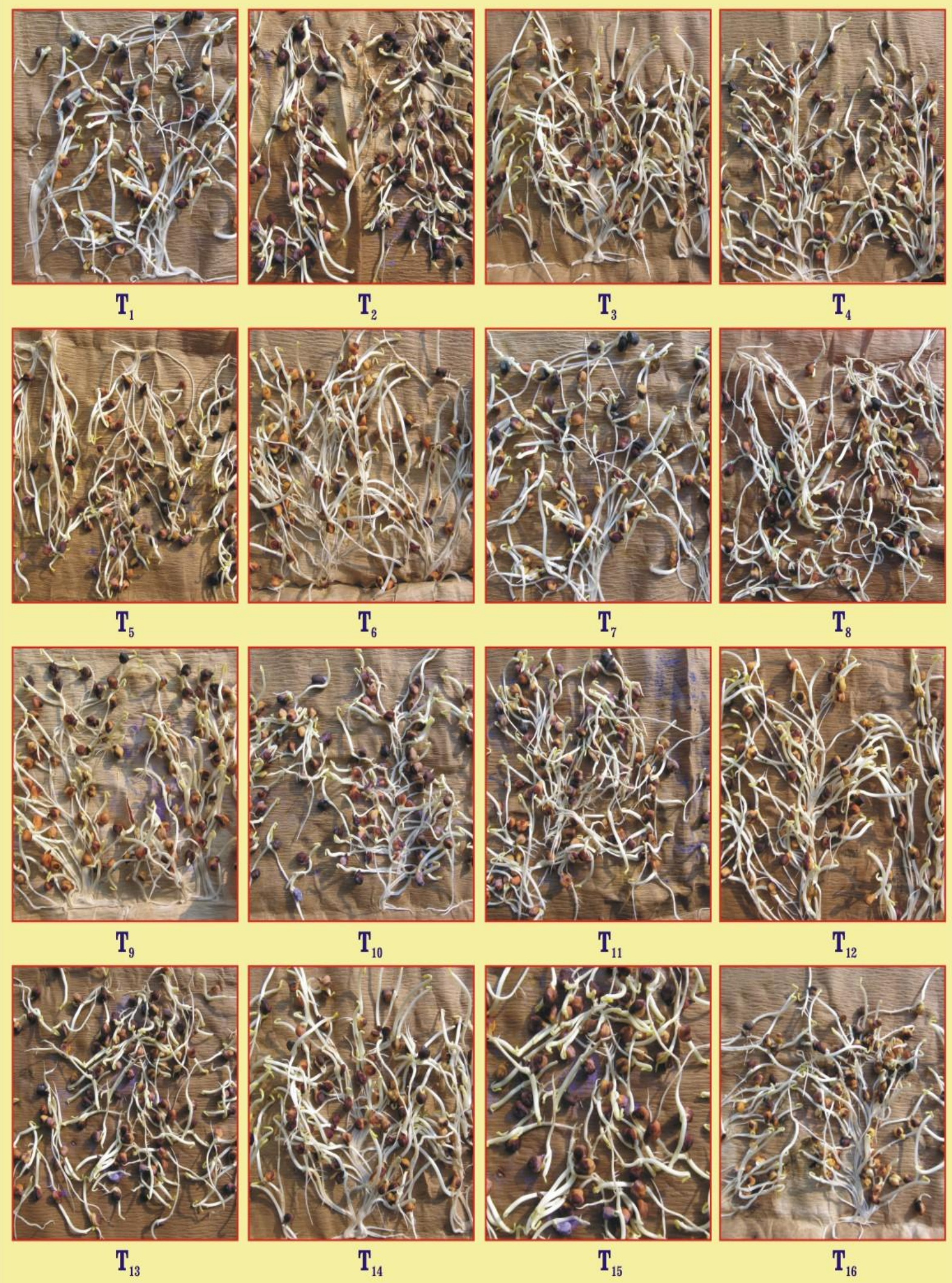

Fig.1 


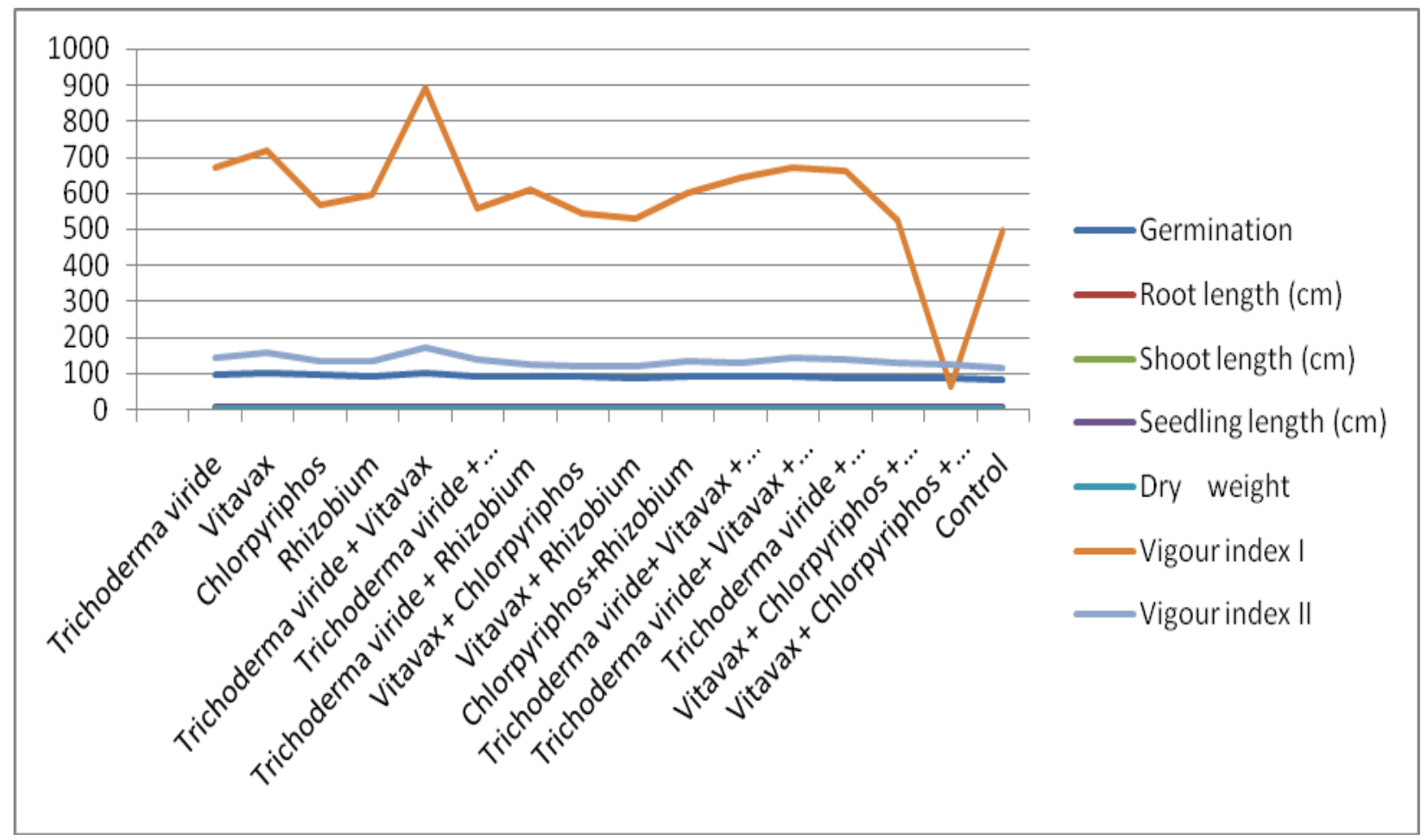

Fig. 2



Fig.3 
On the basis of findings it can be concluded that out of sixteen treatment including control $\mathrm{T}_{5}$ treatment (T.v. + Vitavax) as well as Vitavax are better seed treatments to enhance quality seed parameters, which then converted into superior yield even in adverse conditions. Seed treatment with Trichoderma viride + Vitavax were fund superior for germination $(82 \%)$ and plant survival respectively, seed treatment with bio agent and Vitavax gave the highest yield per plot and found the superior seed treatment. Among all the treatments, Chlorophyriphos + Rhizobium exhibited the poorest performance in most of the character under study over control.

\section{References}

Adams, P. B. (1990). The potential of mycoparasites for biological control of pathogens.Ann. Rev. Phytopathol, 28: 5972.

De, R. K., Chaudhary, R. G. and Naimuddin (1996).Comparative efficacy of bio-control agents and fungicides for controlling chickpea wilt caused by Fusarium oxysporum f. sp. ciceri, India J. of Agril. Sci., 6: 370-373.

Gholev, V. K. and Kurkundkar, B. P. (2002). Biological control of pigeonpea wilt with Pseudomonas fluorescens and Trichoderma viride. India J. Pulse Res., 15(2): 174-176.

Harman, G. E., Latorre, B., Agosin, S., San Martin, R., Riegel, D. G., Nielsen, P. A., Tronsmo, A. and Pearson, R. C. (1996). Biological and integrated control of Botrytis bunch rot of grape using Trichoderma sp. Biological control, 7: 259266.

Kubicek, C. P. and Penttiläme (1998).Regulation of production of plant polysaccharide degrading enzymes by Trichoderma. Trichoderma and Gliocladium. Enzymes, Biological Control and Commercial Applications.49-71.

Ladizinsky, G. and Alder, A. (1976a). Genetic relationship among the annual species of Cicer L .Theor. Appl. Genet., 48: 197-203.

Mukhopadhyay, A. N. (2009). Challenges, changes and choices before Trichoderma based biopesticides, J. Mycol. Pl. Pathol., 39: 542.

Mukhopadhyay, A. N., Shrestha, S. M. and Mukherjee, P. K. (1992).Biological seed treatment for control of soil borne plant pathogens. F. A. O., Plant Prot. Bult., 40(12): 21-30.

Singh, K. B. and Dahiya, B. S. (1973).Breeding for wilt resistance in chickpea. In: Symposium on Wilt Problem and Breeding for Wilt Resistance in Bengal Gram. Indian Research Institute, New Delhi, India, 13$14 \mathrm{pp}$.

Singh, S. K., Sharma, V. P., Sharma, S. R., Kumar, Satish and Tiwari Mugha (2006). Molecular characterization of Trichoderma Taxa causing green mould disease in edible mushroom. Current Sci., 90(3): 427-431.

Summerfield, R. J., Virmani, S. M., Roberts, E. H. and Ellis, R. H. (1990).Adaption of chickpea to agroclimatic constraints. In 'Chickpea in the Nineties'. (Eds. van Rheenen HA, Saxena MC) Proc. of the Second International Workshop on Chickpea Improvement. ICRISAT Publishing, India.50-61pp.

Van der Maesen, L. J. G. (1987). Cicer L. Origin, history and taxonomy of chickpea. 11$34 \mathrm{pp}$.

Verma, R. K. and Vyas, S. C. (1977).Effect of treatment with systemic fungicides in gram wilt control. Pesticides, 2: 20-21.

\section{How to cite this article:}

Ravi Prakash Mishra, Manjul Pandey, Vibhuti Gupta and Deepali Bakshi. 2020. Efficiency of Seed Treatment for Control of Chick Pea Wilt Disease caused by Fusarium oxysporum F. sp. ciceri. Int.J.Curr.Microbiol.App.Sci. 9(12): 3109-3115.

doi: https://doi.org/10.20546/ijcmas.2020.912.369 